\title{
Biochemical changes during heat stress in productive animals with an emphasis on the antioxidant defense system
}

\author{
Daria Mylostyva $^{(\text {iD }}$ | Vasyl Prudnikov ${ }^{\text {iD }}$ | Oleksandr Kolisnyk ${ }^{\text {iD }}$ | Anna Lykhach ${ }^{(\text {iD }}$ | \\ Natalia Begma (iD) | Olena Kalinichenko (iD) | Olena Khmeleva (iD) | Roman Sanzhara I \\ Olena Izhboldina (iD) | Roman Mylostyvyi
}

aState Institution "Institute of Gastroenterology of the National Academy of Medical Sciences of Ukraine"; Slobozhanskii av., 96, Dnipro, 49074, Ukraine. bState Biotechnological University, Alchevskykh Street, 44, Kharkiv, 61002, Ukraine.

'Faculty of Livestock Raising and Water Bioresources, Department of Animal Biology; National University of Life and Environmental Sciences of Ukraine, Heroiv

Oborony Street, 15, Kyiv, 03041, Ukraine.

dDnipro State Agrarian and Economic University, Sergii Efremov Str., 25, Dnipro, 49600, Ukraine.

*Corresponding author: mylostyvyi.r.v@dsau.dp.ua

\begin{abstract}
The problem of free radical pathologies in high temperatures in animal husbandry and veterinary medicine is extremely important scientific and practical. In the process of hyperthermia, the structure of cell membranes, the permeability of membranes, and membrane transport systems change, which cause the oxidation of unsaturated fatty acids and the accumulation of toxic products of a radical nature. This plays an important role in the development of many pathological conditions. The review article describes the problem of the influence of heat stress (HS) on a living organism and the problem of hyperthermia in animal husbandry. Emphasis is placed on the role of the body's antioxidant system in a state of HS and the use of antioxidant drugs as additives into feed for farm animals, aimed at mitigating the course and harmful effects in HS. On the one hand, our goal was to describe in an accessible form the main complex biochemical disorders in the body under HS conditions, which lead to a deterioration in the welfare and loss of productivity of animals. On the other hand, we tried to show the special role of the antioxidant defense system in preventing the development of oxidative stress in its classical representation. Also, we substantiated the choice in favor of using natural and synthetic antioxidants as one of the strategies for the prevention of HS in modern animal husbandry.
\end{abstract}

Keywords: cows, dairy farming, hyperthermia in animal husbandry, mitigation

\section{Introduction}

Today, one of the key problems in animal husbandry is the HS condition in animals, which occurs in the summer and is accompanied by significant economic losses. In recent years, periods of hot weather have occurred more often and last longer, which negatively affects the physical condition of the animals.

HS remains an unrecognized problem in modern dairy farming. However, the financial losses from its harmful influence in European countries are on average estimated at more than 400 euros per cow per year. At the same time, dairy cattle are susceptible to HS, which is one of the reasons for the significant decrease in productivity. In addition, economic losses are caused by the deterioration of the health of animals and the quality of the milk obtained due to the state of hyperthermia (St-Pierre et al 2003; Piron and Malinin 2015; Dos Santos et al 2021).

Under the influence of short-term HS in dairy cows, the decrease in productivity can be $10-35 \%$. More prolonged body exposure to elevated temperatures leads to a further decrease in resistance and reproductive function (Ihsanullah et al 2017; Mylostyvyi and Izhboldina 2021).

HS is defined as a slight increase in the internal temperature above its normal range. This, first of all, concerns high-yielding cows, which generate more heat due to the larger volume of feed consumed, which is associated with an increased heat released during metabolism. The comfort zone, or the so-called thermoneutral zone for dairy cows, varies from -15 to $+25^{\circ} \mathrm{C}$ (Buryakov et al 2016).

Therefore, dairy cows are usually kept at moderate to slightly lower ambient temperatures. They are ideal for both forage harvesting and animal life and for maintaining their well-being at the proper level.

Relative humidity also plays a role in $\mathrm{HS}$, so the temperature-humidity index (THI) is greatly important in animal husbandry. It is a combination of temperature and humidity as a threshold for determining the state of HS.

In this assessment, it was previously thought that the lowest THI limit at which cows would develop HS was 72, covering a temperature range of 23.9 to $32.2{ }^{\circ} \mathrm{C}$ and relative humidity of $65 \%$ to zero. However, today, as milk production 
per cow continues to increase, the lowest THI cut-off point has shifted to 68 , including a temperature range of 22.2 to $26.7{ }^{\circ} \mathrm{C}$ and relative humidity of $45 \%$ to zero. Whereas at 22 ${ }^{\circ} \mathrm{C}$ and $10 \% \mathrm{RH}$ (THI 65), most cows will show no signs of stress at all. Raising the temperature to $27{ }^{\circ} \mathrm{C}$ and the relative humidity to $35 \%$ ( $\mathrm{THI} 73$ ) will double the animal's respiratory rate to 75 per minute.

It should be noted that the HS intensity in animals depends not only on the THI value but also on the duration of their stay in stressful conditions. So, for example, the influence of the ambient temperature of $22{ }^{\circ} \mathrm{C}$ at a relative air humidity of $50 \%$ (THI 68) for 4 hours a day or more led to a decrease in milk production by $1 \mathrm{~kg}$ of milk per day (KhelilArfa et al 2014; Buryakov et al 2016).

\section{Biochemical changes in the body with HS, affecting productivity}

The traditional hypothesis of decreased productivity in HS has been that high ambient temperatures reduce nutrient intake. Nevertheless, the American scientists Baumgard and Rhoads (2013) refuted this opinion, proving that low productivity indicators are associated with impaired carbohydrate metabolism and circulating basal and stimulated insulin concentration changes. According to these authors, this leads to a disruption in the use and synthesis of glucose by myocytes and hepatocytes during hyperthermia and a decrease in the mobilization of fats from adipose tissue against the background of a decrease in sensitivity lipolytic factors (Baumgard and Rhoads 2013).

In addition to all this, dairy cows suffering from HS often experience a decrease in milk fat, which is significantly detrimental to producers in the challenging conditions of the current dairy market. However, data research shows that optimizing rumen function can help maintain milk fat concentration in HS cows.

The decrease of milk fat is due to changes in the rumen: hydrogenation of unsaturated fatty acids and the emergence of certain hydrogenation intermediates from the rumen (e.g., trans-10, cis-12 CLA). These hydrogenation intermediates subsequently interfere with the expression of genes involved in the synthesis of fats, thereby reducing milk fat synthesis in the udder. In addition, an increased rate of rumen evacuation of feed may increase the likelihood of hydrogenation intermediates passing through the rumen (Baumgard and Rhoads 2013).

Another potential mechanism for reducing milk fat during HS involves the concentration of lipopolysaccharides in the rumen (LPS), which are formed from gram-negative bacteria when they die. Research results indicate that with a decrease in rumen $\mathrm{pH}$, the concentration of LPS increases, which leads to a decrease in the concentration of milk fat. The concentration of LPS in the rumen also increases as the proportion of grain in the feed increases, which is fed to maintain energy balance. However, the fat content in milk decreases (Sharifyanov et al 2008).

This relationship may be due to the ability of LPS to initiate insulin production in the pancreas. Increased insulin circulation and sensitivity to it during HS can reduce fat mobilization. This condition can occur in cows suffering from $\mathrm{HS}$, even though the energy balance is negative, with a decrease in feed intake and increased livelihood needs.

In addition, the deficiency of non-esterified fatty acids in blood plasma, as a potentially important precursor of fat milk synthesis, during HS, may contribute to a decrease in milk fat. Another adverse effect of LPS on the production of fatty acids includes a decrease in lipoprotein lipase activity and a decrease in the biosynthesis of lipoprotein lipase and a transport protein of fatty acids. As well as inhibition of enzymes associated with the formation of fatty acids in the udder tissues (Habibian et al 2015).

High temperatures cause dyspnea and sweating in animals to increase as cooling is increased by evaporation. Shortness of breath dramatically increases the loss of carbon dioxide through the lungs, thereby reducing the concentration of carbonic acid in the blood and leading to a critical balance of carbonic acid, bicarbonate, necessary for optimal maintenance of the concentration of hydrogen ions $(\mathrm{pH})$ in the blood. This, in turn, causes respiratory alkalosis.

In a state of hyperthermia, the concentration of adrenaline and norepinephrine in the blood of animals increases, which leads to an increase in the rate of passage of feed in the gastrointestinal tract and a decrease in feed consumption. The stress hormone cortisol has a stimulating effect on the synthesis of oxytocin, which in turn reduces milk flow. Also, cortisol suppresses the immune and reproductive system (causes violations of the reproductive cycle, delays ovulation). Also, it leads to a decrease in the production of milk protein (Sejian et al 2010).

Alhussien et al (2018), in their work, indicate that the state of hyperthermia can have a pronounced negative effect on implanted embryos in cows. This is due to the fact that blood neutrophils react to the implanted embryo and reduce its activity to ensure a successful pregnancy. Furthermore, since it is quite difficult for the immune system to maintain a balance in the HS state, this can negatively affect the safety of the fetus.

Trifković et al (2018) found that HS impairs colostrum quality in fresh cows. In combination with thermal discomfort, this caused a violation of physiological, biochemical, hormonal parameters and oxidative stress, which was confirmed by blood samples taken from calves after the completion of drinking.

During heat stress, the risk of rumen acidosis increases significantly (Timoshenko et al 2016). This is associated with a decrease in feed consumption, especially its volumetric part, a decrease in the supply of saliva (buffer) to the rumen, and a slowdown in rumination. As a result of acidosis, feed conversion deteriorates, the fat content in milk decreases, and milk production also decreases.

From a biochemical point of view, acidosis is the accumulation of the end product of glycolysis e.g., lactate, which is obtained by anaerobic glycolysis, the reactions of which end with the formation of only 2 ATP molecules and the accumulation of lactate. At the initial stage, under 
conditions of a lack of oxygen, the rate of aerobic oxidation in the mitochondria decreases. This leads to a decrease in the amount of ATP and an increase in the content of adenosine diphosphate (ADP) and adenosine monophosphate (AMP) and, as a consequence, to a decrease in the ATP/ADP + AMP ratio. In turn, at a low ATP/ADP + AMP ratio, the activation of hexokinase is triggered, which makes it possible to dramatically increase the throughput of anaerobic glycolysis reactions (Vladimirov 1998).

The cells of the body, under these conditions, begin to consume glycogen, providing themselves with energy due to the anoxic breakdown of glucose. At this stage, adaptation to hypoxia and energy exchange stabilization can still occur. However, such stabilization is usually short-lived and is accompanied by rather rapid depletion of glycogen reserves since anaerobic glycolysis is unable for a long time and in full to provide the body's energy needs (Vladimirov 1998).
In the early stages of oxygen deficiency, cellular acidosis can be considered a protective reaction of the body since a decrease in $\mathrm{pH}$ stabilizes cell membranes. However, a persistent state of acidosis at the cellular level causes specific proteins to be denatured.

The increased release of lactate during hypoxia leads to metabolic lactic acidosis, which blocks gene activity and limits adaptation. At this stage of hypoxia, a true ATP deficiency is formed in the cell since the aerobic mechanism does not work due to oxygen deficiency, and the anaerobic mechanism does not work due to acidosis. In this regard, resistance to hypoxia is formed due to the restructuring of energy pathways, which involves the mobilization of mechanisms for the supply of protons for oxidative phosphorylation and the economical use of missing oxygen (Buryakov et al 2016).

The main biochemical disorders in the body of animals under HS are summarized in Table 1.

Table 1 The main biochemical disorders in heat stress lead to a decrease in animal productivity.

\begin{tabular}{|c|c|c|c|}
\hline Targets & The nature of the damage & $\begin{array}{l}\text { Tissues/organs that are } \\
\text { involved }\end{array}$ & Authors \\
\hline $\begin{array}{l}\text { Carbohydrate, lipid } \\
\text { metabolism }\end{array}$ & $\begin{array}{l}\text { Change in basal and stimulated insulin. Disorder of the } \\
\text { use and synthesis of glucose. Change in insulin } \\
\text { sensitivity. }\end{array}$ & $\begin{array}{l}\text { Muscles, liver, pancreas, } \\
\text { udder }\end{array}$ & $\begin{array}{l}\text { Baumgard and Rhoads } \\
\text { (2013) }\end{array}$ \\
\hline $\begin{array}{l}\text { Morphological } \\
\text { disorders in cells }\end{array}$ & $\begin{array}{l}\text { Increase in mitochondrial size, fragmentation of the } \\
\text { Golgi apparatus, and endoplasmic reticulum }\end{array}$ & Cell organelles & Rivera et al (2003) \\
\hline $\begin{array}{l}\text { Structural disorders } \\
\text { in cells }\end{array}$ & Destruction of DNA proteins & Cell nucleus and nucleolus & $\begin{array}{l}\text { Vanderwaal et al } \\
\text { (2009) }\end{array}$ \\
\hline $\begin{array}{l}\text { Proteins of } \\
\text { biomolecules }\end{array}$ & $\begin{array}{l}\text { Increased synthesis of free radicals, oxidation of } \\
\text { proteins }\end{array}$ & The immune system & Habibian et al (2015) \\
\hline $\begin{array}{l}\text { Secretion of } \\
\text { hormones }\end{array}$ & $\begin{array}{l}\text { Secretion of glucocorticoids, acceleration of cellular } \\
\text { metabolism, increased reactive generation of oxygen } \\
\text { and nitrogen }\end{array}$ & Endocrine system & Gildikov (2020) \\
\hline $\begin{array}{l}\text { Regulation of free } \\
\text { radical formation }\end{array}$ & Increased reactive oxygen species & Antioxidant defense system & $\begin{array}{l}\text { Zbarovskiy and } \\
\text { Bannikov (2014) }\end{array}$ \\
\hline $\begin{array}{l}\text { Organ and tissue } \\
\text { cells }\end{array}$ & $\begin{array}{l}\text { Activation of the release of catecholamines, } \\
\text { adrenaline. Increase in lipid peroxidation products. } \\
\text { Development of oxidative stress }\end{array}$ & Antioxidant defense system & $\begin{array}{l}\text { Vladimirov (2012); } \\
\text { Meschaninov and } \\
\text { Scherbakov (2015) }\end{array}$ \\
\hline
\end{tabular}

In addition to all of the above, HS causes several morphological changes in the cell, which leads to swelling and an increase in the size of mitochondria, fragmentation of the endoplasmic reticulum, and the Golgi apparatus (Rivera et al 2003). Destructive changes also affect the structure of the nucleus, and the nucleolus, in turn, subject to disintegration. When exposed to high temperatures, many proteins are released from the nucleolus. For example, nucleolin binds RPA (Replication protein A) and inhibits DNA synthesis. Another nucleolus protein, nucleophosmin (B23), is also translocated into the nucleus during hyperthermia (Vanderwaal et al 2009).

In their work, a group of scientists shows that with HS, so-called stress granules are formed in the nucleus and cytoplasm (Jolly et al. 2002). In turn, the formation of cytoplasmic stress granules is associated with changes in the functioning of the cell translational apparatus (Kedersha and Anderson 2009).

\section{Oxidative stress and the role of the antioxidant system}

Hyperthermia stimulates the generation of reactive oxygen species (ROS), which induce lipid peroxidation processes. They lead to chemical modification and destruction of molecules due to the development of hypoxia, which accompanies almost all tissue damage. This leads to uncoupling of oxidative phosphorylation and disruption of ATP synthesis, which, in terms of the uniformity of the body's response, can be compared with stress damage (Bacherikov et al 2006).

Some of the main ROS are superoxide radical $* 02$ singlet oxygen 102, hydroxyl $* \mathrm{OH}$ and peroxide $* \mathrm{HO} 2$ radicals, hydrogen peroxide $\mathrm{H} 2 \mathrm{O} 2$, peroxide ion $\mathrm{HO} 2-$, hypochlorite $\mathrm{HOCl}$.

A distinctive feature of all radicals is that they have an unpaired electron at the external energy level, have their magnetic effect; despite their short lifetime, they are very reactive and can initiate chain reactions (Vladimirov 1998). 
It is customary to differentiate ROS into three types:

- primary (inducing), which are formed during the oxidation of some molecules. These include superoxide anion O2- and nitric oxide NO. They have a regulatory effect;

- secondary, formed as a result of the attack of superoxide of other molecules. These include hydroxyl radical $\left(\mathrm{OH}^{\circ}\right)$, peroxynitrite (ONOO-), and lipid radicals. A strong toxic effect characterizes radicals of this type due to their ability to damage membrane lipids, DNA, and protein molecules irreversibly;

- tertiary radicals formed due to the combination of secondary radicals with molecules of antioxidants and other easily oxidized compounds.

Their role in the body of animals can be different (Novikov et al 2014). However, the end product of free radical oxidation reactions is the formation of hydroperoxides of organic molecules in the peroxidation of unsaturated lipids in membranes (Xin et al 2003). In the presence of metal ions with variable valence, these products trigger chain reactions of oxidative degradation of molecules with the formation of lipid radicals, peroxides, and hydroperoxides (LPO). LPO can be carried out in a non-enzymatic way and with the participation of lipoxygenases and cyclooxygenases.

ROS can also be generated upon the inactivation of many xenobiotics in the body. This process involves the microsomal system of cytochrome P-450 localized in the membranes of the endoplasmic reticulum, which leads to the hydrophilicity of the xenobiotic and a decrease in its activity, and then it is excreted from the body.

Under stress and decompensation of the body's antioxidant defense mechanisms, excessive activation of free radical lipid oxidation reactions with the accumulation of primary and secondary peroxidation products contributes to the development of oxidative stress (Simonova et al 2010; Dorovskikh et al 2011; Simonova et al 2014).

The same opinion was reached by Belhadj Slimen et al (2015), who assigns a special place to metabolic disorders in the pathogenetic mechanism of changes in the productivity of animals under the influence of HS. They also note that changes in the stationary concentration of free radicals and the development of cellular and mitochondrial oxidative stress against this background are integral to the imbalance of internal homeostasis in animals.

An increase in the synthesis of free radicals and oxidative damage of proteins, lipids, and DNA molecules during hyperthermia is evidenced by the data of Habibian et al (2015) on the example of broiler poultry. They indicate that additional heat stress can influence the immune response, altering the expression of cytokines and leading to a greater susceptibility of immune cells to oxidative stress (Figure 1).

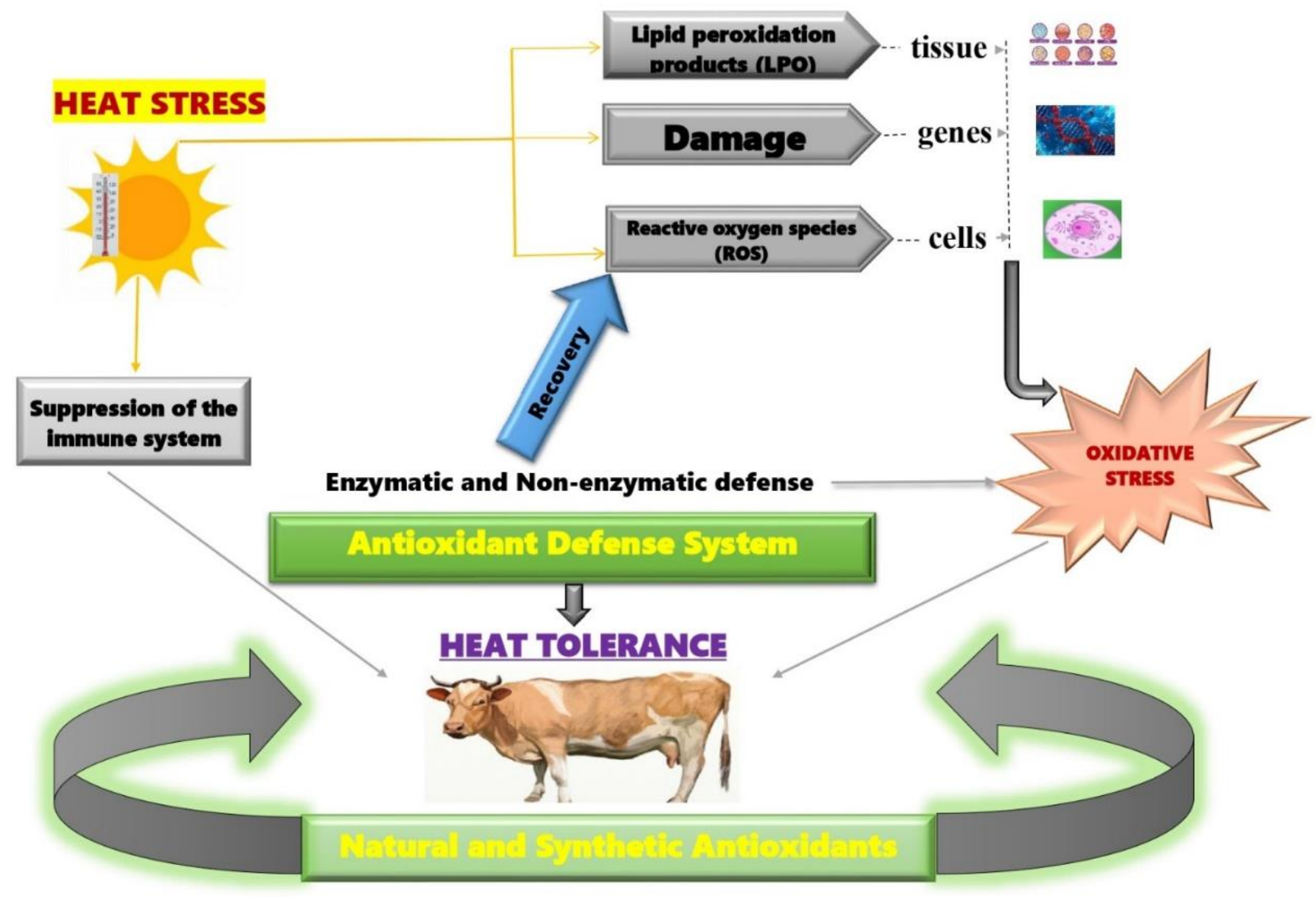

Figure 1 The role of the antioxidant defense system when exposed to heat stress. 
Numerous stress factors that animals are exposed to in modern industrial complexes (Milostiviy et al 2017; MotaRojas et al 2020), lead to increased production of reactive oxygen species, causing stress and, in some cases, depletion of antioxidant defense mechanisms (Lyubin et al 2013; Zbarovskiy and Bannikov 2014). Many scientists point to a close relationship between the development of a stress response, changes in hormonal levels, and oxidativeantioxidant balance in the body (Sklyarov et al 2020). It is believed that changes in internal homeostasis under stress necessarily involve a powerful induction of free radical generation (Chauhan et al 2014; Hall et al 2014).

According to Gildikov (2020), acute stress leads to rapid secretion of glucocorticoids, accelerates cellular metabolism, and increases the reactive generation of oxygen and nitrogen.

Decreased oxidative stress compensation and insufficient recovery accelerate cellular aging. Increased energy expenditure is required to prevent all oxidative damage in cells (Blatt et al 2010).

One of the main mechanisms in developing metabolic disorders that reduce health reserves under stress is the activation of lipid peroxidation and disruption of the sequence of chemical reactions of the antioxidant system. In addition, it is known that the stress response causes the release of catecholamines by the adrenal glands, the inactivation of which in the cytochrome P-450 system is accompanied by the generation of superoxide anions and the formation of oxidative stress (Vladimirov 1998).

According to Novojilov et al (2013), during the development of a stress reaction, the blood system is an intermediary between the hypothalamic-pituitary-adrenal system and body tissues and one of the first body tissues that undergo oxidative stress due to direct contact with oxygen.

In studies carried out on rats by Meschaninov and Scherbakov (2015), it was found that under stress, neurotransmitters of the vegetative nervous system directly affect the change in the intensity of lipid peroxidation processes. Under stress, adrenaline contributes to a rapid and significant increase in the intensity of LPO processes, and acetylcholine contributes to a long-term but less significant change in lipid peroxidation. This is supported by the results obtained in the experiments of Huang et al (2015), who found that when exposed to HS on broiler poultry, the mitochondrial complex is inhibited, which is due to the development of oxidative stress. At the same time, the authors noted that the revealed violations were recorded against the background of changes in the activity of antioxidant enzymes and an increase in the concentration of TBA-active products.

Since the temperature in the body during HS exceeds the maximum values of natural temperature, the stress state of the body at elevated temperatures is associated with hightemperature exposure, which changes the structure of protein molecules and causes thermal denaturation of enzymes.
Although the activation of the body's antioxidant system is a universal adaptive response, in hyperthermic conditions, it has its distinctive features. They are associated, in particular, with a significant effect on antioxidant reactions of a large number of compounds that are not considered to be classical antioxidants. These are such as proline, sugars, polyamines, among others. These compounds are a scavenger of reactive oxygen species and are in complex functional interactions with other antioxidants (Liang et al 2013; Yang et al 2014).

\section{Use of antioxidants as a forage mitigation strategy for HS}

Since dairy cattle react very sharply to an increase in ambient temperature, which causes a change in physiological processes, balanced feeding of animals during this period is very important. High-yielding cows are more likely to be affected by HS than low-yielding ones since they consume more feed and generate more heat during digestion (Simonova et al 2010).

Different foods produce different amounts of heat when they are digested, mainly due to the efficient use of nutrients or different amounts of heat generated during the fermentation of the food. Edible fats have a lower heat output than acetate due to their greater use efficiency. Due to the high energy utilization threshold, the "surplus" of metabolic heat is generated less. When roughage is consumed, heat production is greater than when concentrates are consumed, again due to lower efficiency than acetate, propionate, and glucose and microflora activity. The advantage of reducing metabolic heat production is that less "excess" heat needs to be dissipated subsequently. Furthermore, lower energy costs directly depend on this, especially at high environmental humidity (Nurzhanov et al 2019).

Changes in feeding, first of all, should be aimed at compensating for the decrease in the consumption of dry matter of feed with HS, maintaining the mineral balance, providing animals with the necessary nutrients, and rumen health (Ostapchuk et al 2019).

Optimization of the feeding regimen assumes the transfer of the time of distribution of feed to cool hours $30 \%$ of the daily ration in the morning, $70 \%$ in the evening and at night), free access of cows to clean cool water, an increase in the frequency rate, and the use of special feed additives. It is recommended to use highly digestible feed with a cut length of $1.5-2.0 \mathrm{~cm}$ to prevent the animals from overloading the feed. Feeding diets low in fiber and high in energy and concentrated feed, which should be $60-65 \%$ in the diet structure, minimizes HS in dairy cows due to a decrease in the heat of fermentation (Kedersha and Anderson 2009).

According to Andreeva and Safronov (2019), to prevent acidosis, animal diets should not include a large amount of bulky feed (up to $28-30 \%$ of the neutral detergent fiber in dry matter). The content of non-digestible protein in the diet should be monitored, and its level should be $40 \%$ dry matter. The use of feed additives for HS with a high solid fat 
content is common practice in animal husbandry, as the digestion of fats is accompanied by little heat.

Their sources can be traditional additives (oils, animal fat) and those containing the so-called "protected" fats: up to 6-7\% in the dry matter of the diet of highly productive cows.

Therefore, experts suggest feeding additional protected fat and yeast probiotics (made from live yeast) during HS. Yeast promotes the utilization of lactic acid in the rumen, optimizing the $\mathrm{pH}$ of the rumen. The addition of fat leads to a decrease in the amount of heat generated during the digestion of feed and an increase in the amount of available energy (Farkhutdinova 2015).

Another step in the fight against HS is introducing the diet of highly productive cows of special biotic preparations based on strains of microorganisms Saccharomyces cerevisiae. The processes of lactic acid utilization are activated. In the rumen, live yeast stimulates the development of cellulolytic microflora, optimizes the $\mathrm{pH}$ of the rumen fluid, and improves the digestibility of fiber and protein, which can increase milk yield by up to $6 \%$, as well as milk fat concentration and dry matter intake (Carocho and Ferreira, 2013).

Currently, the problem of antioxidant disorders has gone beyond the scientific and theoretical spheres. Bioactives are promising natural products that reduce HS and support animal metabolism during this challenging period. In practical veterinary medicine, an enzymatic link is functionally distinguished in the antioxidant defense system. It includes the following enzymes: superoxide dismutase, catalase, peroxidase, ceruloplasmin, glutathione peroxidase, glutathione reductase, and a non-enzymatic link: vitamin $\mathrm{E}$, total thiols, protein thiols, reconstituted glutathione, general antioxidant activity, the antiradical activity of blood lipids (Hall et al 2014; Ludan and Polskaya 2019). The search, characterization, and application of natural antioxidants remain the focus of numerous research groups worldwide, and natural antioxidants are today one of the most popular topics in the field of food and agriculture (Nijveldt et al 2001; Pashtetskiy and Nevkrytaya 2018).

For animals, many antioxidants are vitamins. As a result, they are essential components of nutrition. First of all, this concerns phenolic compounds because most animal organisms do not have enzymes to synthesize aromatic structures (Simonova et al 2014). It has been shown that antioxidant vitamins (carotenoids, ascorbic acid, alphatocopherol) protect low-density lipoproteins from oxidation.

Lyubina (2015), in her research, confirms that stimulation of the enzymatic and non-enzymatic links of the antioxidant defense system can be successfully carried out by introducing vitamin preparations with food. Optimization of the antioxidant status with the help of vitamin A and its precursor beta-carotene, which have a wide range of biological properties, seems relevant.

The data obtained in the studies of Nurzhanov et al (2019) indicate that the weakening of the stress state in animals due to the use of antioxidants (kresival and ionol) had a positive effect on their meat productivity and meat quality.
Antioxidants, which contain salicylic acid amides, can effectively destroy peroxyl radicals and molecularly destroy hydroperoxides during oxidation. The antiradical activity of inhibitors is likely due to the presence of phenolic hydroxyl in their chemical structure, and the ability to degrade hydroperoxides is associated with the presence of an amide group (Perevozkina 2015). It was also reported that exogenous succinic acid in small doses, significantly increasing the body's resistance to adverse environmental influences, is a powerful antioxidant. These circumstances determined the conduct of scientific research to study the effect of sodium succinate in the system of measures to ensure cows' health in dairy farming.

The water-soluble veterinary antioxidant Emicidin (a derivative of 3-hydroxypyridine and succinic acid) with a pronounced antihypoxic effect, used for all types of diseases accompanied by increased production of free radical compounds, may be promising for HS (Novikov et al 2014).

Laushkina (2011), in her research, provides data that this drug inhibits lipid peroxidation, increases the activity of the body's antioxidant system and has a membraneprotective and membrane-stabilizing effect, improves energy metabolism in the cell, increases the body's resistance to the effects of various damaging factors in pathological conditions.

The studies carried out by a group of authors have shown (Dorovskikh et al 2017) that it is possible to optimize the function of mitochondria, prevent the uncoupling of oxidation and phosphorylation, increase energy production with the subsequent normalization of energy-dependent processes and increase the activity of the antioxidant system in HS by introducing exogenous succinate.

Selected micronutrient supplements also play an important role as exogenous antioxidants. In particular, the biological role of selenium in the body is stimulating metabolic processes and immunity. Selenium is included in the active center of such an enzyme as glutathione peroxidase, which is the main component of the antioxidant system and is involved in reducing the activity of LPO processes. Some researchers have noted a significant effect of selenium on the morphological and biochemical composition of the blood. Selenium takes part in tissue respiration, regulates redox processes, synthesizes 12 ATP, affects the activity of phosphatases, and affects immunocompetent cells, increasing the body's resistance, increasing the productivity and reproductive functions of the reproductive apparatus (Golubkina and Papazyan 2006; Golova and Vudmaska 2012).

Salerno et al (2007) showed that vitamin E (tocopherol) also plays an important role in the work of the antioxidant system. Tocopherol plays one of the key roles in membranes in building the antioxidant system. However, the cell's antioxidant defense also depends on the degree of recycling of this vitamin.

According to the data of individual researchers (Neuzil et al 2001; Khuzhakhmetova and Teply 2016), alphatocopherol is involved in the antioxidant protection of serum 
lipoproteins, stabilizes the structure of cell membranes, destroys most active oxygen metabolites, can activate genes involved in the induction and inhibition of apoptosis. In their studies, Mudron and Rehage (2018) also note that vitamin E and selenium have anti-stress and antioxidant effects when exposed to stress.

\section{Final Considerations}

Currently, HS is one of the problems of dairy farming due to the imbalance between the influx of heat from the environment and the release of heat by the body, which occurs in the summer and brings significant economic losses. The effects of HS in cows can be minimized by creating optimal housing and feeding conditions. The introduction of special feed additives (such as solid fats, buffers, yeast, and minerals) into the diet, especially antioxidants, should be the basis of feed strategies for HS, taking into account the development of a state of oxidative stress in the animal body.

\section{Conflict of Interest}

The authors declare that they have no conflict of interest.

\section{Funding}

This research did not receive any financial support.

\section{References}

Abilov Al, Javoronkova NV, Nasibov SHN, Abilova SF (2015) Influence of heat stress on the reproductive ability of dairy cows of the black-and-white breed fertilized with Holstein. Modern Trends in The Development of Science and Technology 2:108-115.

Alhussien MN, Kamboj A, Aljader MA, Panda BSK, Yadav ML, Sharma L, Mohammed S, Sheikh AA, Lotfan M, Kapila R, Mohanty AK, Dang AK (2018) Effect of tropical thermal stress on peri-implantation immune responses in cows. Theriogenology 114:149-158.

Andreeva D, Safronov S (2019) Heat stress and its prevention in cattle. Bulletin of the Student Scientific Society 10:114-115.

Bacherikov AN. Kuzminov VN, Tkachenko TV, Nazarchuk AG (2006) Modern ideas about the system of thermoregulation. Bulletin of the psychiatrist. Pharmacotherapy 1:178-182.

Baumgard LH, Rhoads RP (2013) Effects of Heat Stress on Postabsorptive Metabolism and Energetics. Annual Review of Animal Biosciences 1:311-337. doi: 10.1146/annurev-animal-031412-103644

Belhadj Slimen I, Najar T, Ghram A, Abdrrabba M (2015) Heat stress effects on livestock: molecular, cellular and metabolic aspects, a review. Journal of Animal Physiology and Animal Nutrition 100:401-412.

Blatt T, Wenck H, Wittern K-P (2010) Alterations of Energy Metabolism in Cutaneous Aging. Farage MA, Miller KW, Maibach HI (eds) Textbook of Aging Skin. Springer, Berlin. pp 295-312. doi: 10.1007/978-3-540-89656-2_29

Buryakov NP, Buryakova MA, Aleshin DE (2016). Heat Stress and Heat Stress and Feeding Features of the Dairy Cattle. Russian Veterinary Journal 3: 5-13.

Carocho M, Ferreira ICFR (2013) A review on antioxidants, prooxidants and related controversy: Natural and synthetic compounds, screening and analysis methodologies and future perspectives. Food and Chemical Toxicology 51:15-25. doi: 10.1016/j.fct.2012.09.021

Chauhan SS, Celi P, Leury BJ, Clarke IJ, Dunshea FR (2014) Dietary antioxidants at supranutritional doses improve oxidative status and reduce the negative effects of heat stress in sheep. Journal of Animal Science, 92:3364-3374. doi: 10.2527/jas.2014-7714

Chen H-JC, Spiers JG, Sernia C, Anderson ST, Lavidis NA (2014) Reactive nitrogen species contribute to the rapid onset of redox changes induced by acute immobilization stress in rats. Stress 17:520-527.

Dorovskikh VA, Simonova NV, Pereverzev DI, Shtarberg MA (2017) Comparative effectiveness of cytoflavin and its constituent components in experimental oxidative stress. Experimental and Clinical Pharmacology 80:18-22.

Dorovskikh VA., Simonova NV, Simonova IV, Shtarberg MA (2011) Adaptogens of vegetable origin in prophylaxis of respiratory diseases in children of young age. Dal'nevostočnyj Medicinskij Žurnal 1:41-44.

Dos Santos MM, Souza-Junior JBF, Dantas MRT, de Macedo Costa, LL (2021) An updated review on cattle thermoregulation: physiological responses, biophysical mechanisms, and heat stress alleviation pathways. Environmental Science and Pollution Research 28:30471-30485. doi:10.1007/s11356-021-14077-0

Dudin VI (2004) Biochemistry of vitamin E and biologically active substances associated with it. Moscow, Russian Academy of Agricultural Sciences.

Evglevskiy AA, Skibin YUV, Vorobeva NV, Shvets OM, Evglevskaya EP (2011). Theoretical and practical substantiation of the use of an injectable preparation based on succinic acid in alimentary acidosis and ketosis of highly productive cows. Veterinary Pathology 3:67-70.

Farkhutdinova LM (2015) Oxidative stress. History of research. Bulletin of the Academy of Sciences of the Republic of Bashkortostan 20:42-49.

Gildikov DI (2020) Oxidative stress in animals: a pathophysiologist's view. Russian Veterinary Journal 4:10-18. doi: 10.32416/2500-4379-2020-4-10-18

Golova NV, Vudmaska IV (2012) Effect of selenium added to the cows highfat diet on peroxide products in blood plasma, selenium content in milk and milk yields and composition. The Animal Biology 14:230-236.

Golubkina NA, Papazyan TT (2006) Selenium in nutrition. Plants, animals, people. Moscow, Printed city.

Habibian M, Sadeghi G, Ghazi S, Moeini MM (2015) Selenium as a Feed Supplement for Heat-Stressed Poultry: a Review. Biological Trace Element Research 165:183-193. doi: 10.1007/s12011-015-0275-x

Hall JA, Bobe G, Nixon BK, Vorachek WR, Hugejiletu, Nichols T, Mosher WD, Pirelli GJ (2014) Effect of transport on blood selenium and glutathione status in feeder lambs1. Journal of Animal Science 92:4115-4122.

Huang C, Jiao H, Song Z, Zhao J, Wang X, Lin H (2015) Heat stress impairs mitochondria functions and induces oxidative injury in broiler chickens1. Journal of Animal Science 93:2144-2153. doi: 10.2527/jas.2014-8739

Ihsanullah Qureshi MS, Suhail SM, Akhtar S, Khan RU (2017) Postpartum endocrine activities, metabolic attributes and milk yield are influenced by thermal stress in crossbred dairy cows. International Journal of Biometeorology 61:1561-1569. doi: 10.1007/s00484-017-1335-z

Jolly C, Konecny L, Grady DL, Kutskova YA, Cotto JJ, Morimoto RI, Vourc'h C (2002) In vivo binding of active heat shock transcription factor 1 to human chromosome 9 heterochromatin during stress. Journal of Cell Biology 156:775-781. doi: 10.1083/jcb.200109018

Kedersha N, Anderson P (2009) Chapter 4 Regulation of Translation by Stress Granules and Processing Bodies. Translational Control in Health and Disease 155-185. doi: 10.1016/s1877-1173(09)90004-7

Khelil-Arfa H, Faverdin P, Boudon A (2014) Effect of ambient temperature and sodium bicarbonate supplementation on water and electrolyte balances in dry and lactating Holstein cows. Journal of Dairy Science 97:2305-2318.

Khuzhakhmetova LK, Teply DL (2016) Features of free radical processes during immobilization stress in rats in ontogenesis. Natural Sciences 4:72-78.

Laushkina NN (2011) The effect of antioxidants on milk productivity and quality when changing the conditions of keeping lactating cows. Bulletin of the Oryol State Agrarian University 31:51-52.

Liang X, Zhang L, Natarajan SK, Becker DF (2013) Proline Mechanisms of Stress Survival. Antioxidants \& Redox Signaling 19:998-1011. doi: 10.1089/ars.2012.5074

Ludan VV, Polskaya LV (2019) The role of antioxidants in the vital activity. Tavricheskiy Mediko-Biologicheskiy Vestnik 22:86-92.

Lutsky MA (2014) Oxidative stress in the pathogenesis of cerebrovascular 
diseases and stroke. Applied Informative Aspects of Medicine 17:3-7.

Lyubin NA, Stetsenko II, Lyubina EN (2013) The functional state of the antioxidant defense system and free radical oxidation in pigs depending on the use of various forms of vitamin $A$ and beta-carotene. Vestnik of Ulyanovsk State Agricultural Academy 1:54-59.

Lyubina $E$ (2015) Role of mineral elements in the regulation of processes of free radical oxidation on the use of vitamin $A$ and beta-carotene preparations. Vestnik of Ulyanovsk State Agricultural Academy 3:64-68.

Megahed G, Anwar M, Wasfy S, Hammadeh M (2008) Influence of Heat Stress on the Cortisol and Oxidant-Antioxidants Balance During Oestrous Phase in Buffalo-Cows (Bubalus bubalis): Thermo-protective Role of Antioxidant Treatment. Reproduction in Domestic Animals 43:672-677.

Meschaninov VN, Scherbakov DL (2015) Influence of neurotransmitters on lipid peroxidation during immobilization stress exposure in rats of different ages. Kazan Medical Journal 96:843-849. doi: 10.17750/kmj2015-843

Milostiviy RV, Vysokos MP, Kalinichenko OO, Vasilenko TO, Milostiva DF (2017) Productive longevity of European Holstein cows in conditions of industrial technology. Ukrainian Journal of Ecology 7:169-179. doi: $10.15421 / 201766$

Mota-Rojas D, Broom DM, Orihuela A, Velarde A, Napolitano F, AlonsoSpilsbury M (2020) Effects of human-animal relationship on animal productivity and welfare. Journal of Animal Behaviour and Biometeorology 8:196-205. doi: 10.31893/jabb.20026

Momot TV (2015) Stress response and prevention. International Medical Scientific Journal 2:86-88.

Mudron P, Rehage J (2018) Effects of vitamin E and selenium supplementation on blood lipid peroxidation and cortisol concentration in dairy cows undergoing omentopexy. Journal of Animal Physiology and Animal Nutrition 102:837-842. doi: 10.1111/jpn.12897

Mylostyvyi R, Izhboldina O (2021) Problems of livestock reproduction with a focus on climate change. Multidisciplinary Reviews 4:e2021011.

Neuzil J, Weber T, Terman A, Weber C, \& Brunk UT (2001) Vitamin E analogues as inducers of apoptosis: implications for their potential antineoplastic role. Redox Report 6:143-151.

Nijveldt RJ, van Nood E, van Hoorn DE, Boelens PG, van Norren K, \& van Leeuwen PA (2001) Flavonoids: a review of probable mechanisms of action and potential applications. The American Journal of Clinical Nutrition 74:418 425. doi: $10.1093 / a j c n / 74.4 .418$

Novikov VE, Levchenkova OS, Pozhilova YeV (2014) Role of reactive oxygen species in cell physiology and pathology and their pharmacological regulation. Reviews on Clinical Pharmacology and Drug Therapy 12:13-21.

Novojilov AV, Tavrovskaya TV, Ivanov VA, Morozov VI (2013) Hematological parameters and redox balance of rat blood in the dynamics of immobilization. Bulletin of Experimental Biology and Medicine 155:439-442.

Nurzhanov B, Levakhin Y, Dzhulamanov E, Ryazanov V (2019) Assessment of the impact of fat additive with copper nanoparticles on the ruminal digestion of fattening calf bulls. Bulletin of the Buryat State Academy of Agriculture 4:32-37.

Ostapchuk PS, Zubochenko DV, Kuevda TA (2019) The role of antioxidants and their use in animal breeding and poultry farming (review). Agricultural Science Euro-North-East 20:103-117.

Pashtetskiy VS, Nevkrytaya NV (2018) Use of essential oils in medicine, aromatherapy, veterinary and crop production (review) Tavrichesky Bulletin of Agrarian Science 1:18-40.

Perevozkina MG (2015) Salicylic acid amides are new promising antioxidants. Fundamental Research 8:1681-1688.

Piron O, Malinin I (2015) Should heat stress be prevented in dairy cows? Effective Animal Husbandry 3:8-20.
Polhovskaya N (2016) Heat stress: effects on cow productivity. Compound Feeds 6:52-55.

Rivera RM, Kelley KL, Erdos GW, Hansen PJ (2003) Alterations in Ultrastructural Morphology of Two-Cell Bovine Embryos Produced In Vitro and In Vivo Following a Physiologically Relevant Heat Shock. Biology of Reproduction 69:2068-2077. doi: 10.1095/biolreprod.103.020347

Salerno C, Capuozzo E, Crifò C, Siems W (2007) $\alpha$-Tocopherol increases caspase- 3 up-regulation and apoptosis by $\beta$-carotene cleavage products in human neutrophils. Biochimica et Biophysica Acta (BBA) - Molecular Basis of Disease 1772:1052-1056. doi: 10.1016/j.bbadis.2007.05.008

Sejian V, Maurya VP, Naqvi SMK (2010) Effect of thermal stress, restricted feeding and combined stresses (thermal stress and restricted feeding) on growth and plasma reproductive hormone levels of Malpura ewes under semi-arid tropical environment. Journal of Animal Physiology and Animal Nutrition 95:252-258. doi: 10.1111/j.1439-0396.2010.01048.x

Sharifyanov BG, Mamleev NSH, Loginova ZV, Enikeev RT (2008) Influence of ration content on rumen digestion of ruminants. Zootechnics 4:15-16.

Simonova NV, Dorovskikh VA, Li ON, Anokhina RA, Shtarberg MA, Simonova NP (2011). Correction of oxidative stress by natural antioxidants. Bulletin of Respiratory Physiology and Pathology 53:84-88

Simonova NV, Dorovskikh VA, Shtarberg MA (2010) Effect of adaptogens of plant origin on the intensity of the processes of peroxidation of lipids of membranes under conditions of ultraviolet irradiation. Far Eastern Medical Journal 2:112-115.

Simonova NV, Dorovskikh VA, Simonova NP (2014) Ultraviolet radiation and oxidative stress. The possibility of phitocorrection. Blagoveshchensk, AGMA.

Sklyarov P, Fedorenko S, Naumenko S, Antonenko P, Zazharskyi V, Mylostyvy R, Zazharska N (2020) Oxidant/Antioxidant Balance in Cows and Sheep in Antenatal Pathology. Ukrainian Journal of Ecology 10:26-28.

St-Pierre NR, Cobanov B, Schnitkey G (2003) Economic Losses from Heat Stress by US Livestock Industries. Journal of Dairy Science 86:E52-E77. doi: 10.3168/jds.s0022-0302(03)74040-5

Timoshenko V, Muzyika A, Moskalev A (2016) Heat stress in cows. How to stay productive? Belarusian Agriculture 7:42.

Trifković J, Jovanović L, Đurić M, Stevanović-Đorđević S, Milanović S, Lazarević M, Sladojević Ž, Kirovski D (2018) Influence of different seasons during late gestation on Holstein cows' colostrum and postnatal adaptive capability of their calves. International Journal of Biometeorology 62:10971108. doi: 10.1007/s00484-018-1

Vanderwaal RP, Maggi LB., Weber JD, Hunt CR, Roti Roti JL (2009) Nucleophosmin Redistribution following Heat Shock: A Role in Heat-Induced Radiosensitization. Cancer Research 69:6454-6462.

Vladimirov YUA (1998) Free radicals and antioxidants. Bulletin of the Russian Academy of Medical Sciences 7:43-51.

Xin M-G, Zhang J, Block ER, \& Patel JM (2003) Senescence-enhanced oxidative stress is associated with deficiency of mitochondrial cytochrome $c$ oxidase in vascular endothelial cells. Mechanisms of Ageing and Development 124:911-919. doi: 10.1016/s0047-6374(03)00163-5

Yang B, Wu J, Gao F, Wang J, \& Su G (2014) Polyamine-induced nitric oxide generation and its potential requirement for peroxide in suspension cells of soybean cotyledon node callus. Plant Physiology and Biochemistry 79:41-47. doi: 10.1016/j.plaphy.2014.02.025

Yarovan NI, Petrushina MV, Dementeva ES, Leshin VV (2012) Prevention of violations of physiological and biochemical status in highly productive cows in industrial conditions. Bulletin of Agrarian Science 34:98-100.

Yoshikawa T, Naito Y (2002) What is oxidative stress? Journal of the Japan Medical Association 124:1549-1553.

Zbarovskiy IA, Bannikov MV (2014) Antioxidant system of the body, its role in metabolism. Monthly Scientific Journal 3:18-22. 